\title{
Growth and Flowering of in vitro-Propagated Lilium auratum Bulbs in Soil
}

\author{
Shinsaku Takayama* and Kiyoshi OHKawa** \\ * Tsukuba Research Laboratory, Kyowa Hakko Kogyo Co., Ltd. \\ 2 Miyukigaoka, Tsukuba, Ibaragi 305, Japan \\ ** Department of Biological Sciences, Faculty of Agriculture, \\ Shizuoka University, Shizuoka-city, Shizuoka 422, Japan
}

(Received May 29, 1990)

(Accepted August 13, 1990)

\begin{abstract}
The cultivation in soil of bulblets of Lilium auratum propagated by tissue culture was inves. tigated. In vitro-produced bulblets of L. auratum grew well in soil and required 3 growing seasons for normal flowering. Flowering time and flower quality were uniform and the plants revealed no virus symptoms. Abnormal flowers (four for five tepals) were observed when the bulbs were less than $15 \mathrm{~g}$, while all flowers were normal ${ }^{-}$when the bulbs were over $15 \mathrm{~g}$. Flower opened within a week and the size distribution of flower tepals revealed a normal distribution curve.
\end{abstract}

Lilies and their hybrids are among the most important bulbous ornamental plants together with the species Tulipa Freesia, and Narcissus. Since Lilium bulbs are difficult to propagate under natural conditions, artificial propagation methods such as bulb-splitting, scaling, or stem-cutting are used. ${ }^{1)}$ However, these methods are problematic because production of a large number of genetically homogenoeus plants is difficult, and moreover, deterioration occurs in cut flowers infected with viruses.

Lilium auratum is the most slowly growing species and the species most infected with viruses among 15 wild Japanese Lilium species. ${ }^{2)}$ It was introduced to Europe in $1861,{ }^{2)}$ and became popular because of its large flower and strong fragrance. L. auratum bulbs are produced commercially by collecting wild bulbs in their natural habitat and growing them in the field for one year; then fully grown bulbs are harvested and shipped. Recently, however, the natural resources of this species have rapidly disappeared. The substituted bulb-production methods of $L$. auratum are propagation by scaling, seeds, and bulbils. Unfortunately, few bulbils are produced; furthermore, their size is too small. Scaling is widely used in propagation of various Lilium species, but in the case of L. auratum, scales easily deteriorate during scaling. The use of seeds is the only practical method for propagation, but this method is problematic because of the phenotypical variation by genetical segregation and because of the extraordinarily slow growth of the bulbs until flowering in practical terms for 4 to 5 years.

Given this background, a practical mass propagation method for Lilium auratum was developed, using tissue culture techniques. ${ }^{3-5}$. In the present report, bulb growth and flowering characteristics of in vitro-propagated bulbs of $L$. auratum in soil are described.

\section{Materials and Methods}

Bulbs of Lilium auratum Lindl. cv. No. 10 selected from wild bulbs ${ }^{6)}$ were propagated through in vitro culture methods. ${ }^{5)}$ These bulbs were transplanted to soil (volcanic soil-bark $=3: 1, \mathrm{v} / \mathrm{v}$ ) on September 7, in the first year after low temperature treatment at $4^{\circ} \mathrm{C}$ for 60 days, and then grown in a greenhouse at $30-15^{\circ} \mathrm{C}$ day-night temperatures under natural solar radiation. The subsequent cultivation in soil was performed according to similar schemes. The bulbs were harvested on April 1 in the 
second year, weighed, chilled at $4^{\circ} \mathrm{C}$ for 60 days, transplanted into the soil on May 31 in the second year, and grown in the greenhouse with the same conditions as mentioned above. The bulbs were harvested on November 20 in the second year and weighed. Then the bulbs were transplanted into the soil on December 1 in the second year, chilled under natural conditions, and grown in the greenhouse as mentioned above(bulbs less than $8 \mathrm{~g}$ ) or in an isolation net-house in the field (bulbs over $8 \mathrm{~g}$ ). The bulbs flowered in the end of July in the third year.

\section{Results}

Establishment and growth of tissue-cultured Lilium auratum plants in soil

Most bulbs produced by tissue culture methods were less than $1 \mathrm{~g}$ (Fig. 1). After the first year of cultivation in soil, the mean weight of the bulbs increased to $3.0 \pm 1.8 \mathrm{~g}$, but no flowering plants were

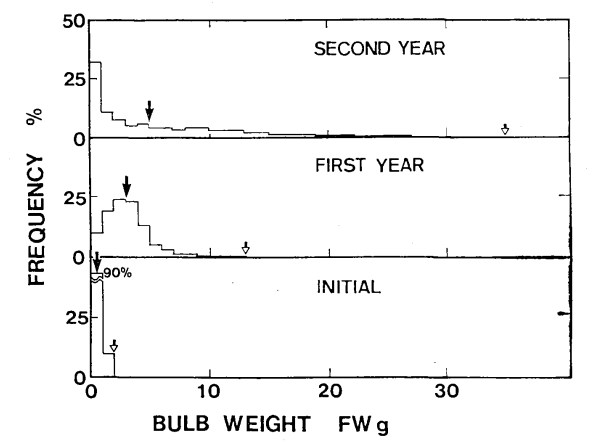

Fig. 1. The enlargement of Lilium auratum bulbs after cultivation in soil.

INITIAL : Bulbs produced by tissue culture. FIRST YEAR: Weight distribution of bulbs after cultivation in soil for the first year. SECOND YEAR: Weight distribution of bulbs after cultivation in soil for the second year. $\downarrow$ =mean weight and $\downarrow$ =maximum weight (FW) of bulbs.

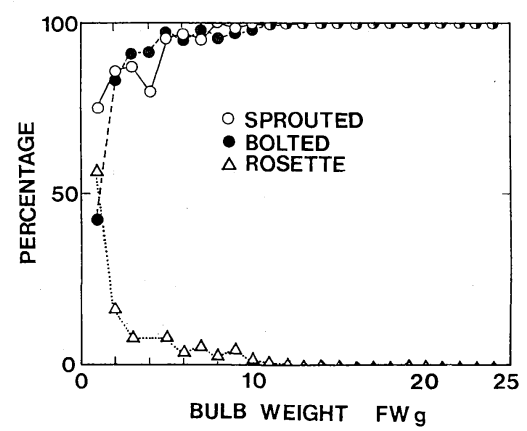

Fig. 2. Relationship between initial bulb weight and type of growth of Lilium auratum plants in the third year of cultivation in soil. The percentages of bolted and rosette plants were calculated against the number of sprouted plants.

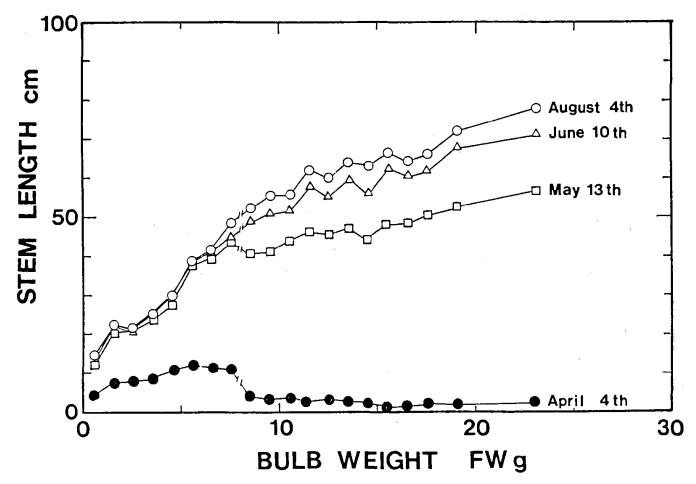

Fig. 3. Relationship between initial bulb weight and pattern of growth (stem length) of Lilium auratum plants in the third year of cultivation in soil. The bulbs were transplanted into soil on December 1, 1981, and plant growth (stem length) was measured on the dates in 1982 as indicated in the figure. 

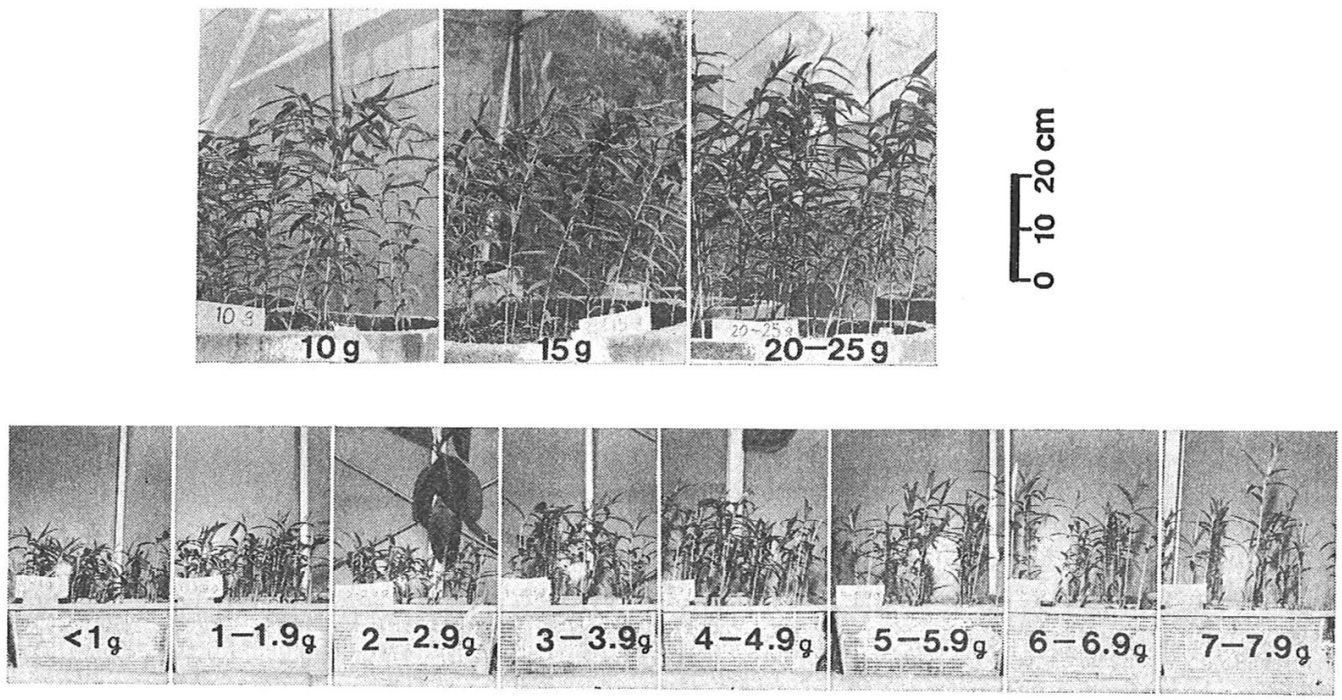

Fig. 4. Growth characteristics of Lilium auratum plants in the third year of cultivation in soil. Photographs were taken on April 7 in the third year for bulbs of 0 to $8 \mathrm{~g}$ (lower row), and on May 13 in the third year for blubs over $8 \mathrm{~g}$ (upper row). The bulbs were transplanted into soil as indicated in Fig. 3, and photographs were taken in 1982 . Values in the photographs indicate the bulb weight.

observed. In the second year, bulbs grew to $5.0 \pm 5.2 \mathrm{~g}$, and a few plants flowered. In the third year, plants grown from bulbs over $10 \mathrm{~g}$ flowered.

Only 80 to $90 \%$ of plants sprouted when bulbs less than $5 \mathrm{~g}$ were planted (Fig. 2). Sprouting percentage rose to $95 \%$ when the weight of planted bulbs was 5 to $10 \mathrm{~g}$, and reached $100 \%$ when the bulb weight was more than $10 \mathrm{~g}$. Bolting was also related to the weight of bulbs. When the bulb weight was less than $1 \mathrm{~g}$, only $40 \%$ of bulbs bolted. The percentage of bolted plants rose as the bulb weight increased, and reached $100 \%$ when the bulb weight was more than $10 \mathrm{~g}$.

The bulbs smaller than $7 \mathrm{~g}$ grown in a greenhouse sprouted on March 15 in the third year. The most rapid increase in plant height was observed from April to May in these bulbs; after that, the growth rate decreased (Fig. 3). The bulbs larger than $8 \mathrm{~g}$ grown in an isolating net-house in the field sprouted early in April, and then grew rapidly during May to June; after that, growth rate decreased. Plant height reached maximum at anthesis (Figs. 3 and 4).

During the third year of cultivation of L.auratum plants in soil, not all plants survived (Fig. 5). The death of the plants was closely related to the initial bulb weight. When bulbs of less than $1 \mathrm{~g}$ were planted, only about 35\% still survived by August 4th. The percentage of surviving plants increased as the initial bulb weight increased, and almost all plants survived when the bulb weight was over $10 \mathrm{~g}$ (Fig. 5). The observation on June 20 in the third year revealed that flower buds were formed only in the plants whose initial bulb weight was over $5 \mathrm{~g}$ (Fig. 6). However, development of flower buds stopped and failed to open in the plants whose initial bulb weight was 5 to $8 \mathrm{~g}$. Most flower buds developed and flowered normally whose initial bulb weight was over $8 \mathrm{~g}$, especially over $10 \mathrm{~g}$.

\section{Flowering}

Flower opening (anthesis) of L. auratum plants during the third year of cultivation began on July 25 in the third year (Fig. 7). The number of flowering plants increased day by day, reached a maximum on July 31 in the third year, and the flower opening ended on August 6 in the third year. Within the week from July 28 to August 4, 80.3\% (448 out of 558) of the plants flowered.

Flower size (tepal length) was about $16 \mathrm{~cm}$ regardless of the initial bulb size and their size distribu- 


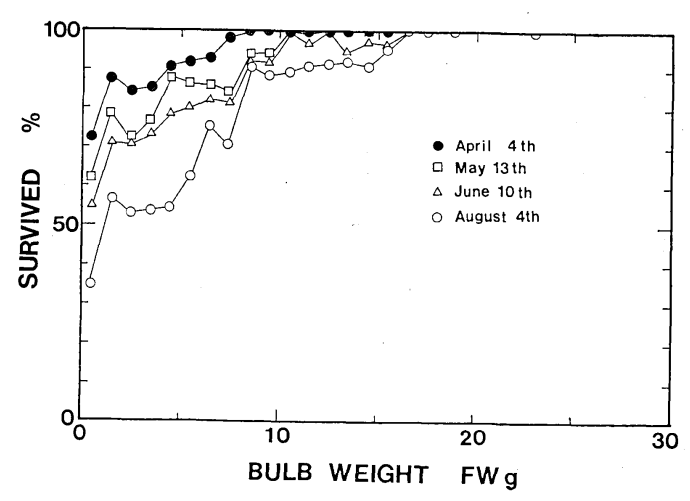

Fig. 5. Effect of initial bulb weight on \% survival of Lilium auratum plants at four dates during the third year of cultivation in soil.

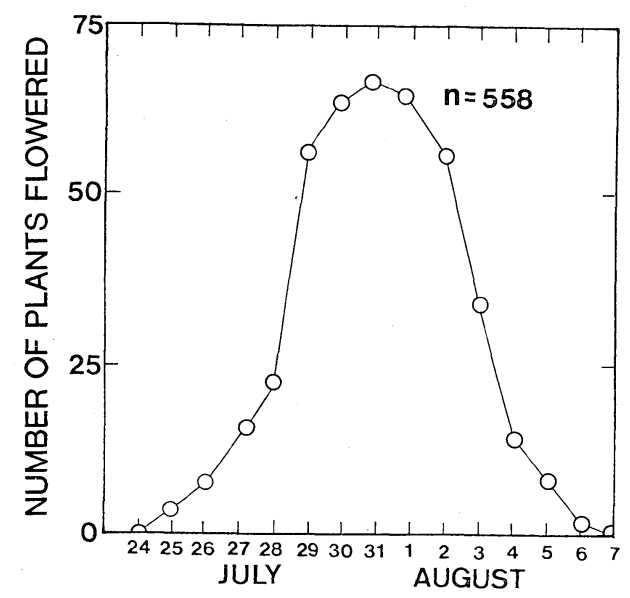

Fig. 7. Flower opening of Lilium auratum plants at different dates during the third year of cultivation in soil.

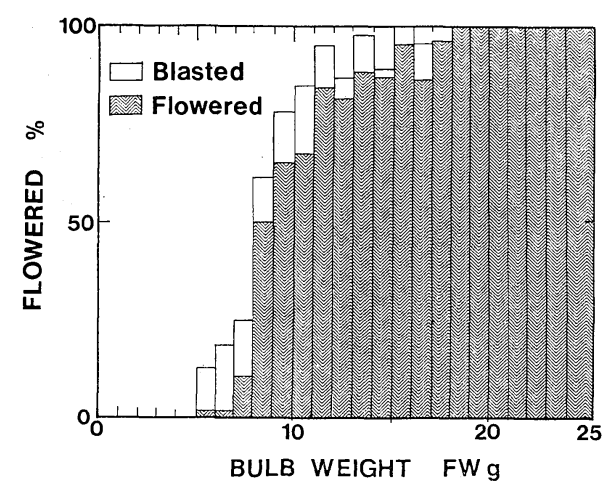

Fig. 6. Flowering (\%) and blasting (\%) during the third year of cultivation in soil of Lilium auratum plants in relation to initial FW of bulbs.

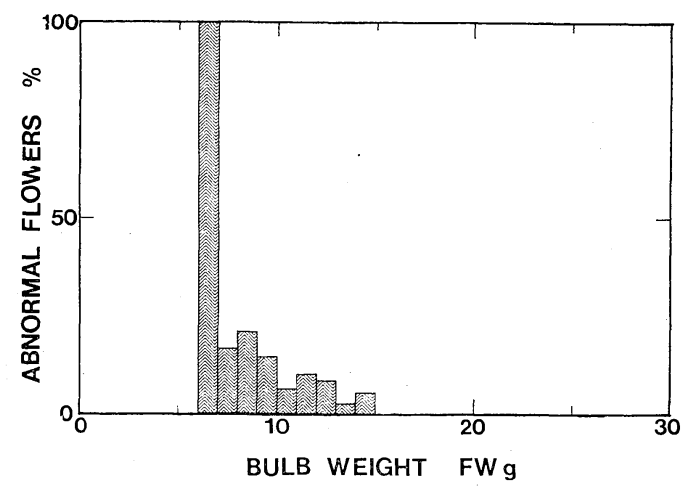

Fig. 8. Relationship between initial bulb weight and formation of abnormal flowers with 4 or 5 tepals in Lilium auratum plants in the third year of cultivation in soil.

tion was similar to a normal distribution curve (data not shown).

Some abnormal flowers consisting of four or five tepals were observed when the bulbs were less than $15 \mathrm{~g}$, while all flowers were normal when the bulbs were over $15 \mathrm{~g}$ (Fig. 8).

\section{Discussion}

Some important results have been reported concerning tissue culture propagation of Lilium bulbs. Lilium viruses are eliminated or disinfected using shoot tip cultures, ${ }^{7-11)}$ and their micropropagation using serial subculture of bulb-scales dissected from in vitro-produced bulblets ${ }^{12-14)}$ or using callus. ${ }^{15,16)}$ In spite of these results, bulbs propagated by tissue culture techniques were smaller and difficult to establish in soil or compost. ${ }^{17)}$ In practice, virus-free bulbs produced by shoot tip culture are propagated using conventional propagation techniques. ${ }^{17)}$ Takayama and Misawa $(1983)^{5)}$ studied the possibility of mass propagation of bulbs using tissue culture techniques, and proposed a mass propagation scheme 
for lilies, especially for $L$, auratum. The plants of $L$. auratum grown in soil flowered at the third year of cultivation in soil. This is about two to three years faster than conventional methods of growing from seeds, which requires 5 or more years. This indicates the practical use of established tissue culture methods as a tool for vegetative propagation of lily bulbs.

The phytopathological and morphological examinations proved the excellent quality of these flowers. Flowering time and flower quality were uniform and the plants revealed no virus symptoms.

Notwithstanding the uniform and healthy characteristics of the bulbs, some flowers became morphologically abnormal with four or five tepals. : However, the result in this report shows that this abnormality occurred in the flowers of bulbs less than $15 \mathrm{~g}$, which are immature for flower opening. Therefore, stimulation of bulb maturation will be indispensable for commercial mass propagation of Lilium species. The temperature in mid-summer in Kanagawa Prefecture, where the plants were grown, seemed to be too hot for $L$. auratum plants, though the optimum environmental conditions for the growth of $L$. auratum have not yet been established. The control of environmental conditions for large-bulblet production in vitro will be an important research area for mature bulb production of $L$. auratum.

\section{References}

1) Hartmann, H. T., D. E. Kester, 1975. Plant propagation: Principles and Practices, 3 rd ed., PrenticeHall, Inc., New Jersey.

2) Inoue, Y. (ed.), 1983. Encyclopedia of Horticulture, Vol. 7., p. 56-92, Seibundou Shinkousya, Tokyo.

3) Takayama, S., M. Misawa., Y. Takashige, H. Tsumori, K. Ohkawa, 1982. J. Am. Soc. Hort. Sci., $467:$ 830-834.

4) Takayama, S., M. Misawa, 1983 a. Can. J. Bot. 61: 224-228.

5) Takayama, S., M. Misawa, 1983 b. Sci. Hortic., 18: 353-362.

6) Ohkawa, K., 1982. Kanagawa Engeishikenjo Kaki Shiken Seisekisyo, p. 65.

7) Aartrijk, J.V., G. J. Blom-Barnhoorn, P. C. G. Van der Linde, 1989. In "Handbook of Plant Cell Culture Vol. 5" (ed. by Ammirato, P. V., D. A. Evans, W. R. Sharp, Y.P.S. Bajaj), p. 535-576, McGraw-Hill Publishing, New York.

8) Allen, T. C., K. Fernald, 1972. Am. Lily Soc., $25: 53-55$.

9) Allen, T. C., 1974. Control of viruses in Lilies. Lilies 1974 and other Liliaceae, p. 3-10.

10) Allen, T. C., R. G. Linderman, 1976. Acta Hortic., 59 : 37-38.

11) Sheridan, W.F., 1968. Planta, $82:$ 189-192.

12) Anderson, W. C., 1977. In Vitro, $13: 145$.

13) Novak, F. J., E. Petru, 1980. Sci. Hortic., $14: 191-199$.

14) Stimart, D. P., P. D. Ascher, 1978. J. Am. Soc. Hort. Sci., 103 : 182-184.

15) Shimmonds, J. A., B. G. Cumming, 1976. Sci. Hortic., 5 : 161-170.

16) Stimart, D. P., P. D. Ascher., J. S. Zagorski, 1980. HortScience, 15 : 313-315.

17) Glasshouse Crops Research Institute, 1982. Virus free bulbs. GCRI pamphlet. 


\title{
《和文要約》
}

組織培養で増殖したヤマユリ（Lilium auratum L.）の育成と開花特性

\author{
高山真策，大川 清* \\ 協和発酵筑波研究所 \\ * 静岡大学農学部
}

組織培養で增殖したヤマユリを土壌に移植栽培し，開花までの球根の育成経過と開花特性について調 べた。組織培養で增殖した球根は, 栽培 3 作目に開花した。球根の生育には大きな差があり, 栽培 2 作 目の収穫時には $1 \mathrm{~g}$ から最大 $35 \mathrm{~g}$ までの重量の差が生じた. 栽培 3 作目の開花時期および花の品質は均 一であり，ウイルス病斑むみられなかった．花被が 4 枚あるいは 5 枚の異常花が観察されたが，乙れは 球根重量 $15 \mathrm{~g}$ 以下の未成熟の球根でのみ発現し, $15 \mathrm{~g}$ 以上ではすべて正常であった。 